\title{
THE FATE OF "NO-FAULT" IN AMERICA
}

\section{Richard Gaskins*}

Outside New Zealand other countries debated possible "no-fault" reforms. Why did other countries not follow the same pattern as New Zealand in the 1960s? This article looks at the different policy outcomes in the United States, where no-fault proposals of limited scale were vigorously debated in the 1960s, and where more comprehensive approaches (including ideas drawn from the New Zealand ACC) struggled to gain political traction amidst the growing trend to litigation in the 1970s. Also taking shape in the United States was a new conceptual approach to the problems of personal injury, using the language and methods of welfare economics, which utterly transformed the academic debate. The writings of Guido Calabresi may suggest how, after 1980, the core definitions and distinctive principles advanced by Woodhouse seemed lost in translation, especially after these American methods found their way into New Zealand ACC debates.

HEW Secretary's Commission on Medical Malpractice: ${ }^{1}$

It may yet come to pass that the most effective remedies for the ills of our tort reparation system will be disclosed by demonstration, in an attractive, usually tranquil, and very civilized little country half-aworld away from the troubled industrial societies with which it shares a common legal heritage ... The developments "down under" thus merit our most careful and continuing observation.

* Brandeis University (Massachusetts, USA). I am pleased to acknowledge support from Fulbright New Zealand and the US Fulbright Commission for my research on comparative compensation policies. My gratitude also goes to the Law Faculty at Victoria University of Wellington for hosting my visit as a Fulbright Scholar in 1999, and on other occasions. In particular, Geoff McLay has been a generous and stimulating colleague. A Fulbright Senior Specialist award made it possible for me to participate in the 2002 conference for which this paper was written. It should be added that several key Fulbright exchanges in the early days of New Zealand ACC played a role in acquainting Americans with the scheme and its history.

1 Arthur H Bernstein "'No-Fault' Compensation for Personal Injury in New Zealand" in United States Department Health, Education, and Welfare Report of the Secretary's Commission on Medical Malpractice (1973) Supplementary Volume 848. Bernstein visited New Zealand and conducted personal interviews in November 1971. 


\section{A DOG THAT NEVER BARKED}

Whenever New Zealanders look back at their unique system of accident compensation, critics of the ACC scheme like to pose a simple question: if the original concept was so marvelous, why has no other country chosen to follow New Zealand's example of comprehensive no-fault? Throughout the 1970s, it was with pride that New Zealanders shared their compensation experiment with international visitors. By the 1990s, however, the tide had shifted, and defenders of the earlier vision found themselves on the defensive. Eventually they encounter that nagging question, what did other countries know that New Zealanders did not? Was there some compelling bit of evidence or theory that pointed others in more promising directions? This line of questioning counts as powerful rhetoric in contemporary policy debates. It also invites a historical response: taking us back to the 1960s, when the pendulum seemed to be swinging in the no-fault direction in most developed English-speaking countries. ${ }^{2}$

Outside New Zealand there were specific political and economic events that blocked the momentum toward no-fault during the 1960s and 1970s_often frustrating international reformers who regarded ACC with admiration. During this same period there also emerged - chiefly in the United States - an intellectual counter-movement to no-fault, confined at first to a body of professional literature based on innovations in welfare economics. It was not until about 1980 that these new ideas gained wide favor, by which time the political pendulum had turned away from nofault solutions. History can help us understand these elusive turning points in the policy processthe results of multiple and countervailing forces. This essay looks back at the "curious incident" of no-fault deliberations that went nowhere. ${ }^{3}$

Entering the 1960's Americans were exploring no-fault ideas in much the same spirit as other outposts of common law culture. ${ }^{4}$ But the debate in America followed distinctive patterns and produced unique outcomes, in starkest contrast to the comprehensive no-fault policy proposed in

2 Throughout this paper I follow the convention of referring to the New Zealand scheme as "ACC", despite its frequent name changes over time. For a history of the scheme and its amendments through the mid-1990s, see Ian B Campbell Compensation for Personal Injury in New Zealand: Its Rise and Fall (Auckland, Auckland University Press, 1996). This paper also refers to the 1967 Royal Commission Report that made the case for comprehensive reform. See Compensation for Personal Injury in New Zealand: Report of the Royal Commission of Inquiry (Government Printer, Wellington, 1967) known as the "Woodhouse Report" after its chairman, Sir Owen Woodhouse.

3 The term "no-fault" is regrettably imprecise. It may refer variously to liability rules (for example liability without fault) or to entitlement to compensation (for example, first-party insurance), or both. Despite the breadth of the term, it was widely used in America and New Zealand, among other places, into the 1970s. It has obvious inadequacies as short-hand for the central philosophy behind ACC. My colleague William Vosburgh points out that "no-fault" was also popularly applied to contemporary reforms of American divorce laws.

4 For a summary of American contributions in comparative context, and with abundant references to the literature, see Alexander Szakats Compensation for Road Accidents (Sweet \& Maxwell, Wellington, 1968). 
1967 in New Zealand. Specific reasons for these differences can be found in American political culture, especially its standard rhetoric of rugged individualism, along with a cumbersome legislative process that confines policy changes - if any-to the margins of social problems. ${ }^{5}$ Beyond these familiar political features there are more arresting and powerful elements in the nofault debate that need to be rescued from historical amnesia. By understanding these distinctive American contributions (and by locating them in historical time), other nations may recognise political and ideological trends that have spread to other systems. In comparative perspective, what emerges from this history is the contrast of two sharply distinct ways of framing the whole compensation problem, each embedded in a particular social vision.

The fate of no-fault in America is a complex tale with many possible interpretations. ${ }^{6}$ Focusing on the 1960s, I want to review several broad tensions that may explain why we ultimately resisted New Zealand-style reforms. It took about 10 to 20 years for American practice to move away from anything approaching the New Zealand model. In retrospect, the key transitions include: (1) shifts in national economic priorities, understood as finding a new balance between social equity and economic efficiency; (2) shifts in political vision, with an eroding confidence in legislation and residual choice for market autonomy; and (3) shifts in academic styles, which would eventually replace traditional no-fault discourse with the new policy vocabulary of welfare economics. By 1980, these changes - working together-were sufficient to block the earlier momentum for nofault, making it difficult for us to remember now what the earlier debate was all about. Americans today scratch their heads when they hear about the New Zealand scheme, whose implementation at home has been shadowed by similar ideological doubts. The fate of no-fault in America previews familiar controversies that would eventually surface in New Zealand.

5 The no-fault debate seriously tested the boundaries of residual individualism, as was pointed out by Theodore J Lowi "The Welfare State: Ethical Foundations and Constitutional Remedies" [1986] Political Science Quarterly 101, 197. Lowi's analysis is a useful corrective to Robert Kagan's recent argument that American constitutional values promote "adversarial legalism" (Adversarial Legalism: The American Way of Law (Harvard University Press, Cambridge, 2001)).

6 This is an appropriate place to acknowledge my appreciation to three colleagues whose interest in New Zealand (facilitated by Fulbright awards) proved contagious. Jane C Kronick, Miriam Vosburgh, and William W Vosburgh (along with others, myself included) received two research grants in the 1970s from the United States National Science Foundation to explore the political, economic, sociological, and legal origins of ACC, with comparative analysis of contemporary debates in the United States. See Jane C Kronick (ed) New Zealand Accident Compensation: Community Responsibility as a Value Response to Technological Development (National Science Foundation, Wellington, 1978) and Value Issues in the Control of Technology-Related Damage (National Science Foundation, Wellington, 1980) [Grants Nos 0SS76-14797 and 0SS78-18023]. Along with Geoffrey Palmer's work (see, for example, Geoffrey Palmer Compensation for Incapacity: A Study of Law and Social Change in New Zealand and Australia (Oxford University Press, Wellington, 1979)) reports from Kronick's group remain the most detailed studies of ACC policy formation. 
My main task here is to investigate what undermined the no-fault debate in America. Two additional parts of the story will be mentioned briefly along the way: (1) the chaotic, cyclical growth of personal injury litigation in America, caused arguably by energy that might have been rechanneled into no-fault legislation; and (2) new public perceptions of risk and responsibility that emerged in the 1970s wave of environmental regulation, and that remain in constant tension with our current policies on compensation and prevention.

\section{A Social Priorities and the Role of Government}

During the first days of the Kennedy administration, back in the early 1960s, many Americans were still asking how government could best contribute to the general welfare. Common discourse on the "accident problem" implied there were concrete solutions-even bold solutions, by our standards - that could be engineered and maintained by political authorities. ${ }^{7}$ In this respect, Americans caught up in "no-fault" debates shared common political assumptions with the rest of the developed world. As the spotlight fell on highly visible losses of accident victims, especially in automobile accidents, it revealed the wasteful traditional methods of filtering compensation through judicial fault doctrines. ${ }^{8}$

In broad political terms, the decade began with a call to public action by President Kennedy, who had campaigned against the "do-nothing" Eisenhower era. This passive image of government was often ridiculed by the dynamic captains of Kennedy's administration. His chief economic advisor, Walter Heller, declared that ideas from the likes of Chicago economist Milton Friedman would paralyze government action. Rather than "getting the country moving again," Friedman's reactionary counsel would stop government in its tracks. Friedman's mantra, as Heller later wrote, reversed common sense: "Don't do something, just stand there". 9 By contrast, it was strength and vigor that defined the Kennedy image, and vigorous action was still projected onto State institutions and their charismatic leaders.

7 The modal example of this standpoint is Robert E Keeton and Jeffrey O'Connell Basic Protection for the Accident Victim - A Blueprint for Reforming Automobile Insurance (Little Brown, Boston, 1965). A version of this proposal also appeared in (1965) 78 Harv L Rev 329. Another influential work that remained skeptical about reform was Walter J Blum and Harry Kalven Jr Public Law Perspectives on a Private Law Problem-Auto Compensation Plans (Little Brown, Boston, 1965).

8 Prior to Keeton/O'Connell, several studies had documented the plight of victims and various inadequacies of tort remedies. For example, Marc A Franklin, Robert H Canin and Irving Mark "Accidents, Money, and the Law: A Study of the Economics of Personal Injury Litigation" (1961) 61 Colum L Rev 1; Alfred F Conard Automobile Accident Costs and Payments: Studies in the Economics of Injury Reparation (University of Michigan Press, Ann Arbor, 1964). Another version was published as "The Economic Treatment of Automobile Injuries" (1964) 63 Mich L Rev 279.

9 Milton Friedman and Walter W Heller Monetary v Fiscal Policy (Norton, New York, 1969) 34. The occasion was a 1968 debate staged at the Graduate School of Business Administration at New York University. 
And yet, there was less to this muscular statesmanship than the rhetoric suggests. In contrast to state planning in time of war, American leaders found few points of political leverage in the cyclical economic expansion of the post-war era. ${ }^{10}$ Distrustful of social welfare systems modeled in Western Europe, American politicos in the early 1960s passed over the question of how economic gains should be fairly distributed. Increasing national economic wealth was an end in itself during the Cold War era, and distributional fairness (always difficult for Americans to define with any precision) could be left to the invisible hand of markets. For other countries at this time, questions of social equity were more central: a fair distribution of wealth and income was considered the prerequisite condition for economic efficiency and growth. ${ }^{11}$ By contrast, the right-leaning Keynesian advisors to Democratic governments came to argue that equality and efficiency were caught in a massive "trade-off", requiring governments to locate an awkward equilibrium between competing social and economic ideals. ${ }^{12}$

The Kennedy administration buried distributional concerns in the course of internal debates on economic policy. Having recognised the need for fiscal stimulus, the redoubtable Walter Heller wanted to take it in the form of corporate tax cuts to fuel investment. He ultimately prevailed over John Kenneth Galbraith, who had argued for social investment in public goods, including both physical infrastructure and social safety nets. ${ }^{13}$ In retrospect, Heller's vision of economic policy resembled Milton Friedman's retreat from politics more than anyone realised: it scaled down expectations for broad social reform, and called instead for fine-tuning the largely automatic settings of a market economy. The American preference for hidden-hand solutions was inexorably reasserting itself during this decade. Social equity lost its force as a goal of social policy; it became a brake on economic markets, distracting them from fulfilling their autonomous functions. To be sure, race relations and President Johnson's War on Poverty remained part of the equity debate. Except in the courts, however, many Americans concluded that greater equality came at the expense of order and efficiency.

\section{B 1960s: Zeroing in on Automobiles}

This studied avoidance of distributional fairness shaped the original discussion of personal injury issues, lowering the stakes in the search for no-fault legislation. By the mid-1960s, attention remained focused on automobile accidents, where social equity between established interest groups

10 On this trend generally see Gary Marks "The Revival of Laissez-Faire" in Richard Hodder-Williams and James Ceaser (eds) Politics In Britain and the United States: Comparative Perspectives (Duke University Press, Durham, 1986) chap 2.

11 Richard Titmuss was a representative figure. See Brian Abel-Smith and Kay Titmuss (eds) The Philosophy of Welfare (Allen \& Unwin, London, 1987).

12 Arthur M Okun Equality and Efficiency: The Big Trade-Off (Brookings, Washington DC, 1975).

13 See Bruce Miroff Pragmatic Illusions: The Presidential Politics of John F Kennedy (David McKay, New York, 1976) 170, 204-28. 
played a modest role. By contrast, there had been elements of class conflict between employers and employees back when America adopted workers' compensation - the pioneer no-fault scheme found in most American states by around 1920. In the classless post-war universe of automobile drivers and road accident victims, it was harder to frame the issues of equity. Rather than rescuing some disadvantaged class, no-fault automobile plans redefined fairness at more abstract levels. The main problems were these: accident victims (in the aggregate) received inconsistent treatment in the judicial process, administrative costs of individualised proceedings were high, and private insurance made largely irrelevant the judicial inquiry into personal fault. These problems do not compel any special concern for the welfare of individual victims. Over time, social equity became less important than the efficient use of collective resources. Nonetheless, empirical studies continued to document the impact of this imperfect system on individual accident victims and their families. ${ }^{14}$

While the United States produced no manifestos with anything approaching the scope of Canadian Terence Ison's 1967 study, ${ }^{15}$ there was a flood of academic proposals for correcting the deficiencies of road accident compensation. ${ }^{16}$ Drawing on ideas consolidated in the 1930 s at Columbia University, ${ }^{17}$ these proposals commanded an impressive range of variables and solutions.

14 This position was particularly strong in the influential study by Leon Green Traffic Victims: Tort Law and Insurance (Northwestern University Press, Evanston, 1958).

15 Terence G Ison The Forensic Lottery (Staples Press, London, 1967).

16 The nearest exception is Marc A Franklin "Replacing the Negligence Lottery: Compensation and Selective Reimbursement" (1967) 53 Virginia L Rev 774. The leap beyond existing categories of accidents was not especially bold, given the widely critical perspective on traditional negligence concepts. See, for example, Albert Ehrenzweig Negligence Without Fault: Trends Toward an Enterprise Liability for Insurable Loss (University of California Press, Berkeley, 1951). Two essays worked out some implications of extending workers' compensation to other types of injuries: Roger C Henderson "Should Workmen's Compensation Be Extended to Non-Occupational Injuries?" (1969) 48 Tex L Rev 117; Merton C Bernstein "The Need for Reconsidering the Role of Workmen's Compensation" (1971) 119 U Pa L Rev 992. Americans also like to point to a 1913 article that advocated expansion of workers' compensation: Jeremiah Smith "Sequel to Workmen's Compensation" (1913) 27 Harv L Rev 235. Jeffrey O'Connell first ventured into this wider territory in 1973, basing his extensions on voluntary contractual agreements: Jeffrey O'Connell "Expanding No-Fault Beyond Auto Insurance" (1973) 59 Virginia L Rev 749, but his writings managed to remain painstakingly incremental. One does not find a comprehensive vision until Eli Bernzweig's 1980 book: Eli Bernzweig By Accident Not Design: The Case for Comprehensive Injury Reparations (Praeger, New York, 1980). The major American contributors to the automobile debate were certainly aware of broad "social insurance" alternatives to tort but failed to consider them creatively, whether for reasons of intellectual timidity, political prudence, or plain worry about where the money would come from. Commentators like Harry Kalven were wary of shifting private economic power to the public sphere (Harry Kalven "A Schema of Alternatives to the Present Auto Accident Tort System" (1968) 1 Connecticut L Rev 40); and others pointed to the mid-1960s debate over nationalised health insurance for the elderly, as well as controversies over the War on Poverty, as proof that Americans were not interested in constructing a broader safety net.

17 See essays reprinted in "Compensation for Automobile Accidents: A Symposium" (1932) 32 Colum L Rev 785. See also Fleming James Jr "The Columbia Study of Compensation for Automobile Accidents: An Unanswered Challenge" (1959) 59 Colum L Rev 408. Alan Clayton has reminded me that the American 
Most 1960s planners envisioned some new insurance product that was sheltered, up to a point, from the costly procedures and moralistic rhetoric of tort law. Under legislative ground-rules, private insurers would take over the compensation process, with minimal intervention from the common law system. To bring the full financial impact of car accidents into the insurance calculus, some kind of compulsory framework had to be mandated by legislation. Social problems would be solved when the market provided cheap and reliable insurance for all victims, with limits on costly judicial inquiries into individualised fault. Looking back, the sheer number of accident protection plans adopting this formula may have exceeded the " 57 varieties" touted by one of the leading food marketers of the decade. ${ }^{18}$ One is hard pressed to follow all the details: it was rather a nuanced exercise for full-time planners. So far the American discussion still bears a family resemblance to what took place in Canada, Australia, New Zealand, and elsewhere, at least on the level of automobile accidents. ${ }^{19}$ It was lively enough at the level of academic brainstorming but grew more diffuse at State political levels, where special interest groups managed to weaken the reformist spirit.

In such a climate, by 1966 or so, one might wonder whether ideas from Woodhouse or Ison could have pushed Americans to think in more comprehensive terms. ${ }^{20}$ But our debate evolved quite differently during the later half of the 1960's with the emergence of two new categories of personal injury claims: product liability and (to a lesser extent) medical malpractice. By the end of

literature on automobile liability was active and creative in the period before 1932, and needs to be studied more carefully.

18 Jeffrey O'Connell became an industry in himself, while the subtleties of his serial plans quickly exceeded the blunt realities of American politics. By making such programmes "elective" in nature, O'Connell and others anticipated the turn to consumer sovereignty that marked the decline of political initiatives. For a compilation, see Jeffrey O'Connell and Roger Henderson Tort Law, No-Fault and Beyond (Matthew Bender, New York, 1975).

19 In another field that drew only mild interest in the United States, the concept of no-fault entitlement was applied to victims of crime. See, for example, Paul F Rothstein "How the Uniform Crime Victims Reparation Act Works" (1974) 60 American Bar Association J 1531.

20 Ison's book was barely noticed in the American journals. An exception was Norman Penney ("The Forensic Lottery: A Critique on Tort Liability as a System of Personal Injury Compensation" (1971) 84 Harv L Rev 761) who saw Ison's work as a challenge to the emerging conceptual model of Calabresi. Penney notes at 765 with regret that "no one [that is no American] took [Ison's book] seriously". To hear about the Woodhouse Commission, Americans would have had to follow journals from the United Kingdom, New Zealand, Australia, or Canada. See, for example, D L Mathieson "Royal Commission of Inquiry: Compensation for Personal Injury in New Zealand" (1968) 31 MLR 544, 549 which indicated that "the philosophy of the Report may be exportable". Peter McKenzie published a note on the 1969 White Paper: "Reports on Committees" (1971) 34 MLR 542. A reference to the 1963 New Zealand Report of the Committee on Absolute Liability (chaired by Richard Wild) shows up in a 1968 article by William Vickrey "Automobile Accidents, Tort Law, Externalities, and Insurance: An Economist's Critique" (1968) 33 Law and Contemporary Problems 473. But it was not until Geoffrey Palmer's series of articles in the early 1970s that reliable information came to American publications. 
the decade, any comprehensive no-fault agenda would have needed to include a new range of interest groups - consumers and producers, patients and health providers. These groups were quickly developing adverse interests, shaped by a dynamic but unpredictable common law. To many legal academics at the time, this sudden burst of judicial activity suggested that common law itself would manage reforms on the frontiers of liability. Why turn to unknown legislative solutions, when creative judges could promote steady incremental change?

\section{1970s: Environmentalism and other "crises"}

By 1970, in yet another twist, popular attention focused suddenly on broad matters of safety, public health, and accident prevention. The "environmental decade" had arrived, stimulated by works like Rachel Carson's 1962 classic Silent Spring. ${ }^{21}$ While the old no-fault debate was preoccupied with fine-tuning the compensation process, federal lawmakers addressed a wide range of social risks that were only dimly understood. In contrast to the pervasive incrementalism elsewhere in public policy, the new environmental agenda was creative and comprehensive. Even after its legislative energy was expended, it retained the power to evoke both public idealism and mass anxiety. Today it remains a potent but unpredictable source of challenges to "business as usual".

Also in the early 1970s, alongside environmental control, Congress approved regulatory schemes for occupational health and safety (OSHA) and consumer product safety (CPSA). ${ }^{22}$ In this context, policymakers stumbled across new connections between injury prevention and the existing legal framework for compensation. As the public sphere took on new roles in regulating safety in the workplace and marketplace, it seemed to some like a small step to develop a more coordinated response to the plight of parties already injured. At this same moment, state workers' compensation schemes came under critical scrutiny. In 1972 a national conference laid out an agenda for federal reform of workers' compensation systems if significant local changes were not forthcoming. ${ }^{23}$ Additional statutes were considered during this period that would have federalised state automobile compensation systems, medical malpractice rules, and product liability lawsuits. In the late 1970s environmentalists proposed a federal compensation scheme for victims of hazardous toxic waste. ${ }^{24}$

21 These developments have been summarised at length in the literature. For a recent treatment, see Philip Shabecoff Earth Rising: American Environmentalism in the $21^{\text {st }}$ Century (Island Press, Washington DC, 2000).

22 Occupational Safety and Health Act 84 Stat 1590 (1970); Consumer Product Safety Act 86 Stat 1207 (1972). In 1966 Congress had passed the National Traffic and Motor Vehicle Safety Act 80 Stat 718 (1966).

23 National Commission on State Workmen's Compensation Laws Report to Congress (Government Printing Office, Washington DC, 1972). The Commission was mandated by OSHA as a compromise measure between defenders of State laws and advocates of federalised standards.

24 These developments are covered at length in chapter 7 of my book, Richard Gaskins Environmental Accidents (Temple University Press, Philadelphia, 1989). 
The timing of these developments is important to the no-fault story. During the 1960 s, the desultory no-fault debate remained narrowly focused on automobiles, reduced by lack of ambition for social equity, and eventually overtaken by judicial innovations in the areas of product liability and medical malpractice. At the moment when Woodhouse and Ison were thinking more systematically about compensation, Americans remained cautious and technocratic. In the following decade, however, as public concerns shifted to safety and prevention, the no-fault debate came back with a broader focus. The New Zealand scheme gained its greatest relevance to American debates during the middle of the 1970s. From such diverse standpoints as medical accidents, social security disability, and the social impact of technology, several American agencies sponsored formal studies of the New Zealand scheme. ${ }^{25}$ It was in early 1979 , I recall, that Sir Owen Woodhouse met in Washington with President Carter's Attorney General, Griffin Bell.

Additional pressure for reform came from the common law itself, as personal injury litigation opened up wider scrutiny of consumer products and health services. By the mid-1970s the first of many insurance industry crises appeared, prompting manufacturers and physicians to petition state and federal authorities for legislative relief, aimed variously at common law and the insurance industry. ${ }^{26}$ The federal executive branch convened an Interagency Task Force to address the crisis over consumer products, exploring in greater depth the boundaries between common law and private insurance that had figured in earlier no-fault debates about automobile injuries. ${ }^{27}$ Thus by the period 1975-78, concrete problems in the American system might have pushed us to consider more comprehensive reforms of compensation and prevention policies.

25 For medical accidents, see Arthur H Bernstein "'No-Fault' Compensation for Personal Injury in New Zealand" in United States Department of Health, Education, and Welfare Report of the Secretary's Commission on Medical Malpractice (1973) Supplementary Volume 848. For technology, see Jane C Kronick (ed) New Zealand Accident Compensation: Community Responsibility as a Value Response to Technological Development (National Science Foundation, 1978); Value Issues in the Control of Technology-Related Damage (National Science Foundation, 1980) [National Science Grants Nos 0SS7614797 and 0SS78-18023]. On disability, see the report of economist George Rohrlich (another Fulbright Scholar) on his 1980 visit to New Zealand: George Rohrlich "A Study of Comprehensive Compensation Approaches" submitted to the United States Department Health, Education and Welfare under Grant No 10P-98048-3-01 (1980).

26 For discussion see chapter 3 of Gaskins, above.

27 The Final Report of the Interagency Task Force on Product Liability was submitted in 1978 (Government Printing Office, Washington DC, 1978). In 1977 the same Task Force submitted a volume of Selected Papers and a Legal Study, among other documents. The Final Report is a highly political document, a large part of the drafting having been done by a committee headed by Victor E Schwartz, who became a leading industry lobbyist for federal product liability statutes. See, for example, Victor E Schwartz "Federal Action on Product Liablity-What Has Occurred and What May Occur" (1978) 14 Forum 287. In 1978 the Department of Commerce proposed a formal study of broad compensation systems, but it was never done. "Options Paper on Product Liability and Accident Compensation Issues" (1978) 43 Federal Register 14612. 


\section{Summary: Out with a Whimper}

At this point, then, why did the United States fail to pursue the New Zealand model, beyond funding a few exploratory studies? Why did we not at least follow Australia and the United Kingdom in convening high-profile commissions to explore comprehensive reforms? It was a singular moment of opportunity that would never return, given imminent changes in political ideology and academic thinking that settled in by 1980. To anyone who lived through this period, the answer seems all-too-clear: compromise was simply not possible politically among the competing interests of lawyers, insurers, and claimants, not to mention the escalating conflicts between plaintiff and defendant groups in areas of product liability and medical malpractice. ${ }^{28}$ Given the cumbersome legislative machinery in America, starting with our division of power between state and federal authorities, it was too easy for any single group to block accommodation. Groups that saw advantages to expanding litigation were unwilling to abandon the courts; while their adversaries thought they could limit judicial creativity by targeted legislation. Although Congress passed new social programmes to provide national medical insurance for the elderly and a broader disability benefit, prospects for further strengthening the social safety net were dim. Under all these political circumstances, Americans never managed to give the New Zealand model a serious public hearing. ${ }^{29}$

That might well have been the final word in this historical survey of no-fault in America. But the political constraints were only one phase of the overall drama. In retrospect it is clear that important changes in academic theory were building throughout the same two decades when nofault policies struggled for definition. These changes were pioneered by economists but began drifting over into political science and law during the 1960s. Throughout the 1970s, the no-fault debate changed dramatically on the level of ideas, with the result that prior issues of compensation and prevention were translated into a new conceptual idiom. The difference from earlier debates is truly breathtaking. Along with reframing the central issues, American theorists offered strange and unfamiliar policy remedies, couched in the arcane vocabulary of welfare economics. As these new concepts spread beyond America they eventually encountered comprehensive no-fault models.

28 The research team chaired by Jane C Kronick, above, was asked by the National Science Foundation to address specifically the way New Zealand handled competing interest groups on matters of substance and process. American officials interested in the New Zealand model assumed that our interest groups were beyond compromise, especially in a strategic climate shaped by volatile common law developments. In this respect, not much has changed in the intervening decades. For an update on political aspects of the no-fault debate see Thomas Burke Lawyers, Lawsuits, and Legal Rights (University of California Press, Berkeley, 2002). Burke points out that the American Trial Lawyers Association (ATLA), which was to become a major lobbying force to preserve litigation, opened its Washington office in 1972.

29 When Marc A Franklin returned from a Fulbright visit to New Zealand, he tried to interest Americans in ACC reforms indirectly — not on the level of social philosophy but by emphasising common patterns in the incidence of personal injury: Marc A Franklin "Personal Injury Accidents in New Zealand and the United States: Some Striking Similarities" (1975) 27 Stan L Rev 653. 
Within a few short years, the major questions that had driven the Woodhouse inquiry would fall out of favour, to be replaced by entirely new questions.

Before pursuing this next phase of the story, let me take stock of where the historical evidence has brought us so far. Real history is plotted differently from formula fiction. There are always too many reasons why events turned out as they did, especially with the hindsight of 25 years. Moreover every era reveals countervailing tensions, and the overriding role of fate remains opaque and impersonal in the events I am recounting. My interpretation concludes that Americans never seriously engaged the New Zealand model of accident compensation reform, neither in the relatively passive 1960s nor the more volatile mid-1970s, when domestic debates might have found great relevance in ACC. Except for occasional experts who had travelled to New Zealand, Americans never closely inspected the Woodhouse strategy during this period, and they did not know enough about it to reject it. The combined effects of legislative inertia and interest-group politics narrowed the American debate to incremental adjustments of judicial rules and private insurance practices. Despite the countervailing energy of the environmental movement, Americans were losing confidence in the federal government following the Nixon scandals, bitter resistance to the Vietnam War, and the impact of global economic shocks. Any possible window for major reform closed decisively in the late 1970 s.

In addition, throughout the 1970s the federal judiciary enjoyed exceptionally high regard among political progressives, following a decade of civil rights and civil libertarian reforms imposed by heroic judges. As was noted, State courts had been energetically expanding liability rules after the mid-1960s, and many social liberals preferred to let judges guide any reform. ${ }^{30}$ In contrast to the critiques of common law found a decade earlier in Ison and Woodhouse, many American scholars welcomed the doctrinal activism of State judges. They gradually lost interest in how judicial processes affected individual victims. ${ }^{31}$

30 For a close study of the spread of product liability in a single state jurisdiction, see William Nelson The Legalist Reformation: Law, Politics, and Ideology in New York 1920-1980 (University of North Carolina Press, Chapel Hill, 2001). Throughout the 1960s and 1970s, a favorite phrase of progressive legal scholars was "law [meaning 'litigation'] as an instrument of social change".

31 A defence of common law trends was released in 1984 by an American Bar Association "Special Committee" on the tort liability system: Special Committee of the American Bar Association Towards a Jurisprudence of Injury: The Continuing Creation of a System of Substantive Justice in American Tort Law. Meanwhile little was written on the impact of tort processes on individual victims. After Donald R. Harris and his Oxford colleagues published a major empirical study on that topic in the United Kingdom (Donald R Harris Compensation and Support for Illness and Injury (Clarendon Press, Oxford, 1984)), it took an additional seven years for the leading American research centre on tort law to publish a limited replication of Harris' study (Deborah R Hensler Compensation for Accidental Injuries in the United States (Rand Corporation, Santa Monica, 1991)). 


\section{THE REVOLUTION IN WELFARE ECONOMICS}

It now seems plain that Ronald Reagan's election in 1980 marked an ideological shift to the right in America. Proponents of "free" market policies moved quickly into the open spaces created by declining confidence in government. For anyone who remembered Walter Heller's jibe at Milton Friedman, the joke was now on Heller and his Keynesian followers. Indeed, even as Heller spoke, Friedman's team was replacing the old macroeconomics with the new orthodoxy of monetarism. Friedman himself had just completed his term as President of the American Economic Association in 1967. By 1980 it was respectable to say to governments: "Don't do something, just stand there", when government itself was thought to be the source of social ills.

But it is a mistake to approach this shift as purely a matter of ideology. Just as America started tilting to the right, a new wave of academic theory was changing the old no-fault debate beyond recognition. These new analytical tools, taken over from welfare economics, captivated many compensation theorists on the left and centre-left of the political spectrum, as well as on the right. ${ }^{32}$ The pioneers of this movement advanced their ideas in the name of objective science; but over time their disciples learned how to apply the new tools selectively for partisan advantage. By 1980 market advocates were skillfully exploiting the special affinity between welfare economics and market-based solutions to social problems. They kept their opponents off balance by erecting strong theoretical presumptions against further expansion of compensation rules and safety regulations. Let me first describe how welfare economics changed the no-fault debate in America, and then connect these independent changes to the rightward lurch in American politics.

Welfare economics colonised public policy debates in America during the 1960s for many reasons. One major cause was the professional commitment to impartial scientific inquiry at leading universities. Welfare economics brought nothing in the way of empirical data, but it offered its champions the mantle of objectivity at the level of formal theory. At a time when political debates in America were fragmenting into interest-group polemics, social scientists embraced the idea of rigorous, value-free methods. ${ }^{33}$ A new generation of academics used these analytical tools to insulate their policy prescriptions from standard partisan attack. Guido Calabresi was typical of

32 The so-called "new" welfare economics goes back to the 1930s. See E J Mishan Welfare Economics: An Assessment (North-Holland, Amsterdam, 1969). The "older" welfare economics had been centrally concerned with distributional equity and the active role of government in combating externalities.

33 See Theodore M Porter Trust in Numbers: The Pursuit of Objectivity in Science and Public Life (Princeton University Press, Princeton, 1995) ix. On the appeal of welfare economics to academic lawyers, see Morton J Horwitz "Law and Economics: Science or Politics?" (1980) 8 Hofstra Law Review 905. 
his cohort in bemoaning the "woefully unsophisticated" analyses that "had seemed to support the trend toward nonfault liability", which therefore needed new microeconomic foundations. ${ }^{34}$

Thanks to this academic revolution, the no-fault debate in America shifted onto a new theoretical plane and quickly changed beyond recognition. Indeed, the change was so fundamental that most academics (whether on the left or the right) found themselves facing a new constellation of social problems and relevant data. In my view, this is a rare example of a paradigm change in social science, where a new conceptual system displaced its predecessor by changing the very tools of analysis, and not by force of empirical evidence.

\section{A Efficiency for What Purpose?}

Let me illustrate this conceptual revolution with some examples. Nowhere better to begin than with the term "efficiency", which assumes new meanings in welfare economics, different from its use in documents like the Woodhouse Report. When the Woodhouse Commission described its comprehensive scheme as "efficient", its language reflected the political economy of an earlier era. Woodhouse efficiency referred to the social use of resources drawn from public and private spheres, and dedicated to a democratically defined purpose. These resources were mainly levies or premiums charged to employers through workers' compensation insurance, and fees charged to drivers through motor vehicle insurance. These same resources, said the Woodhouse Commission, could fund broader social objectives in a comprehensive scheme, provided the right to bring personal injury actions had been removed. The resources in question-already earmarked in existing insurance programs - came from individuals and firms but were directed to a larger public purpose. The gain in "efficiency" relates to specific goals defined by the democratic process and embodied in legislation.

By contrast, "efficiency" in the new welfare economics relates to goals generated by unregulated market systems - or, more precisely, goals derived from formal models of consumer sovereignty (and producer sovereignty). People generally think of "efficiency" as a simple relationship of means to ends, but the ends themselves have to come from somewhere. ${ }^{35}$ The new welfare economics presumes that markets are the default source of such norms, and this presumption is built into the method itself. It is not to be confused with an ideology of laissez-faire, although it is easy enough to see why many adherents to this method moved to the right on the political spectrum. ${ }^{36}$ Theorists

34 Guido Calabresi The Costs of Accidents (Yale University Press, New Haven, 1970) 5; see also his article Guido Calabresi "The Decision for Accidents: An Approach to Nonfault Allocation of Costs" (1965) 78 Harv L Rev 713.

35 See the useful discussion in Aaron Wildavsky "The Political Economy of Efficiency" (1967) 8 The Public Interest 30 .

36 Two mainstream economists who tried to separate the ideology from the analytics were E J Mishan, see his collected essays in E J Mishan Economic Efficiency and Social Welfare (Allen \& Unwin, London, 1981) and Amartya Sen On Ethics and Economics (Blackwell, Oxford, 1987). 
with more progressive commitments accepted this presumption in favor of market goals, but were ready to supplement their case with special appeals to extrinsic norms. Their methods were pure; their hearts were in the right place; but even the virtuoso performers must have experienced some cognitive dissonance. If nothing else, they had to acknowledge the non-scientific, "subjective" status of normative appeals that reach beyond the market process. The method itself is brutally clear: primary social goals flow from the logic of market models, although they do not logically rule out corrective goals engineered by politics. This priority reverses the treatment of social goals in the Woodhouse Report and most other contemporary documents on no-fault.

\section{B Changing the Topic}

Along with displacing the very ends of social policy, the welfare economic approach to accidents produced even more fundamental changes. When public policy takes its initial guidance from market signals, the core "problem" of personal injury changes by definition. The problem-set emphasised by Woodhouse, Ison, and others was abandoned over the space of 10-15 years, and a new problem-set was put in its place. Once upon a time, the personal injury "problem" was that of uncompensated harm befalling the victims of accidents, with associated social costs for dependents and society at large. The remedy for this problem, following Woodhouse, was a public scheme that advanced accident prevention, compensation, and rehabilitation with coherence and equity.

By contrast, thanks to the new conceptual models of welfare economics, the personal injury problem changed its name. First and foremost, it became the peculiar problem of ensuring that society does not overcommit resources to the task of accident prevention. This core problem logically dominates all others across the new literature, leaving no analytical room for issues of equity and fairness emphasised by Woodhouse. In trying to solve this problem of conserving resources used for prevention, the pioneers of welfare economics redefine compensation and rehabilitation as consumer commodities, for which market demand (whether real or simulated) tells us, by default, how much is enough. Given this radical change of emphasis, it is not surprising that proponents of welfare economics took little note of the Woodhouse Report. Today's neo-liberal critics of ACC are able to cast broad suspicion on the scheme by simply restating their own central postulates. In current debates, very little depends on concrete facts or evidence, and practically everything depends on how one defines the core social problem.

Such criticisms of ACC began appearing in American writings around $1980^{37}$ and could barely conceal their verdict that the whole framework was wrongheaded. These judgments were imported

37 James A Henderson, Jr "The New Zealand Accident Compensation Reform" (1981) 48 U Chi L Rev 781. An earlier casual dismissal came in Jeffrey O'Connell Ending Insult to Injury: No-Fault Insurance for Products and Services (University of Illinois Press, Urbana, 1975) 73 (describes the New Zealand Act as a "blind alley"). Monroe Berkowitz used a Calabresian framework to criticise funding mechanisms in a lengthy empirical study: The Economics of Work Accidents in New Zealand (Victoria University Industrial Relations Centre, Wellington, 1979). 
into the New Zealand debate in the late 1980s, ${ }^{38}$ where they eventually fostered the 1992 and 1998 legislative reforms. Given the timing, many people associate this critique with the neo-liberal shift in New Zealand politics. Perhaps so; but there was something more than ideology behind the critique, just as there were broader cultural complaints behind the political shifts of the 1980s. Defenders of the Woodhouse philosophy were forced to contend with a new style of argument—one that was increasingly accepted as orthodoxy by many centrists as well as neo-liberals. Echoing similar arguments heard in the United States, some opponents of ACC insisted that their conclusions were scientific rather than political. Behind this claim was the notion that formal theory could guarantee objective results. While vigorous disputes might remain about empirical evidence, the core debate turned on matters of definition.

\section{The Calabresian Moment}

To review just when and how the compensation debate took this decisive turn toward welfareeconomic models, let me return to 1960s America and the respected works of Guido Calabresi-a friend and teacher of several participants in this conference, including me. In a series of articles published during the $1960 \mathrm{~s}$, Calabresi set the stage for his systematic work The Costs of Accidents. ${ }^{39}$ Calabresi was the first (and perhaps the clearest) legal academic to apply welfare economics to accident policy. Moreover his own progressive political commitments were (and remain) a matter of public record. Before long, however, the movement launched by Calabresi was joined by fearless and articulate representatives of the Chicago School, and thereafter the mantle of objective science was vigorously contested by scholars holding adverse policy agendas. Calabresi's personal views on social policy were similar to those of his progressive mentor Fleming James, Jr, and in some imagined history we might find Calabresi as the natural exponent of Woodhouse-style reforms in 1960s America. But that is not what happened, as the logic of welfare economics sent Calabresi off on a different sort of quest.

38 See New Zealand Business Roundtable Review of Accident Compensation (submission to the New Zealand Law Commission 1987) as well as its publication New Zealand Business Roundtable Accident Compensation in New Zealand: A Proposal for Reform (New Zealand Business Roundtable, Wellington, 1990). In 1988 a Fulbright-sponsored symposium examined "The Influence of United States Economics on New Zealand" (NZIER, Wellington, 1988)

39 Guido Calabresi The Costs of Accidents (Yale University Press, New Haven, 1970). It is a matter of interpretation when Calabresi's approach took hold. In the legal academic world, his book and the subsequent debates with Posner and others were widely discussed by the mid-1970s, and achieved something like orthodoxy by 1980 . Prior to 1970 Calabresi's ideas were available to specialists through journal articles, but I concur with Gary T Schwartz, "My impression ... is that the scholarly community had regarded Calabresi's pre-Costs writings as a somewhat esoteric sideshow" (Gary T Schwartz "ForewordTorts Scholarship" [1985] 73 Cal L R 549). The leading commentator in Britain, Patrick S Atiyah, remained dubious through the third edition of his treatise, Patrick S Atiyah Accidents, Compensation and the Law (Weidenfeld \& Nicholson, London, 1980) although Atiyah himself seemed to undergo a conversion to market ideology in the early 1990s. The fifth edition edited by Peter Cane gives a respectful statement of general deterrence theory, but stresses its practical weaknesses (Butterworths, London, 1993). 
At first glance, the most striking fact about The Costs of Accidents ${ }^{40}$ is that it never attempts to reckon what accidents really cost. At no point does Calabresi provide any empirical evidence on the toll or distribution of accident costs - anywhere in the world. ${ }^{41}$ This striking absence underscores the contrast with the Woodhouse Report and Ison's Forensic Lottery, ${ }^{42}$ as well as practically all other contemporary studies of no-fault schemes. The most attentive reader can reach the end of this lengthy tome with no idea how much accidents were costing either the victims or society as a whole. Of course, this was entirely intentional. More than just changing the conversation, Calabresi changed the very language in which personal injury policies were being debated. For him, the central question about "costs" had little to do with victims suffering losses, or with the social programs that would shoulder those burdens. It had to do instead with certain algebraic ratiosmost important the ratio of aggregate costs of compensation and prevention in a unified market. The whole performance is an armchair exercise requiring no measurements, no empirical investigation, no personal interviews, no actuarial tables, and no attention to technology or innovation.

Calabresi's book was brilliantly calculated to answer a single overarching question: when do we know that society is spending too much on accident prevention? ${ }^{43}$ He wanted an answer that was qualitative and not quantitative, algebraic and not arithmetical. In the context of 1960s no-fault debates, the whole question of "optimal prevention" was a novel inquiry that no one else had thought to pursue (although it would soon be raised vigorously by defendant groups in product liability and medical malpractice cases). Had the Woodhouse Commission even formulated this question, it might have said something like this: we need more prevention at the moment; and someday we may recognise when we have done enough, but only after we have done much more. That is not rigorous enough for Calabresi. Additionally, his approach reduces the preferred mechanisms for prevention to economic incentives operating on choices made by individual actors. So powerful is this concept of prevention that it casts automatic suspicion on virtually all the strategies of prevention contemplated by Woodhouse, to the extent they deviate from the incentive pattern attributed to idealised markets.

40 Calabresi, above.

41 The absence of empirical data was mentioned in some early reviews. See Frank I Michelman "Pollution as a Tort: A Non-Accidental Perspective on Calabresi's Costs" (1971) 80 Yale L J 647 and Richard Posner, who noted Calabresi's "weak sense of fact" and also the rare mention of court decisions "and, if I recall accurately, no statutes" in Richard Posner "Book Review: Guido Calabresi The Costs of Accidents: A Legal and Economic Analysis" (1970) 37 U Chi L Rev 636, 643.

42 Terence G Ison The Forensic Lottery (Staples Press, London, 1967).

43 I am aware that my paraphrase of Calabresi's argument uses broader language than what can be strictly formulated within the logic of optimisation theory. I am trying to show how Calabresi projected that theory into a broader rhetorical field—something that the theory itself cannot explain. 
Even more curious than Calabresi's big question was his delphic answer: the costs of prevention should not exceed the costs of compensation. This pulls the discussion even farther away from the standard 1960s debate, which was busily separating the social functions of compensation and prevention, assigning each function to separate institutions. In addition, Calabresi's response begs an obvious further question: if we cap the collective investment in prevention at the limits of total compensation, how much total compensation should we provide? This second-order question receives further oblique answers cast in Calabresi's formulaic style, including the advice that compensation levels should defer to the primary goal of "optimising" investment in prevention. A third-order set of questions deals with potential state regulation of markets, whose very function is to dictate optimal outcomes. These questions too must defer to the goal of optimising investment in prevention. Taken together, these three levels of inquiry popularised a mode of analysis that was strikingly different from anything found in earlier no-fault debates.

\section{D "Internalisation" as a Fundamental Value}

For Woodhouse and Ison, the most serious defects of the prevailing compensation system were the numbers of uncompensated individual victims, as well as inequitably compensated victims as a class. For Calabresi, by contrast, the most serious defect of any compensation system - present or future - is the failure to "internalise" accident costs to the parties that could avoid them most cheaply in the future. For optimal prevention the overriding norm is rational cost accounting, and too much internalising is equally bad as too little. How different this seems from the Woodhouse framework, which articulates a clear standard of social entitlement and builds its reforms on clear principles of fair distribution. The Calabresi framework borrows its social norms from idealised markets, and seeks mainly to ensure that markets are spared the imperfections of externalised costs. This shift creates an entirely new playing field for commentators on accident compensation.

Calabresi does not ignore questions of justice, but he painstakingly removes them to a small final section of his treatise. When he finally steps outside the analytical model to address the topic of justice, his narrative discomfort is painfully obvious. He acknowledges that nothing inside his model can replace the default norms of free markets and consumer sovereignty, which drive the mechanics of allocational efficiency. Any substantive principle of fairness, accordingly, must be "externally" imported from non-scientific sources. The objective analyst must regard the Woodhouse principles (or other principles of justice) as cultural artifacts - as "dat[a] to be dealt with like the climate". ${ }^{44}$ Here, then, is a major historical divide that separates the Woodhouse generation from the Calabresian moment. The Woodhouse Report was keen to embrace substantive principles of justice; after Calabresi, all such norms have become political, subjective, irrational, external, and analytically severed from the theory of accidents.

44 Guido Calabresi The Costs of Accidents (Yale University Press, New Haven, 1970) 292. 
Calabresi was not a market purist — far from it. His book gives ample space to contemporary theories of market imperfections and, indeed, even suggests creative ways to correct them (always in line with what idealised markets would have said). Within a short time, however, Richard Posner and his Chicago School colleagues joined the compensation debate, bringing along a normative perspective that located justice itself within market systems, whose alleged imperfections they sought to rationalise. By the mid-1970s, this rarefied academic debate became polarised on the level of method. These different uses of formal theory inserted themselves into partisan battles over liability, at a time when Americans were trying to cope with zealous courts, beseiged manufacturers and physicians, and gyrating liability insurance costs.

\section{E Back to Politics as Usual?}

Calabresi himself was not detached from the policy debates of his day. From everything we know, his elegant theories of "optimality" were not what brought him into the compensation debate - far from it. As a student of Fleming James, Calabresi wanted to advance a specific part of James's progressive agenda: to expand the judicial doctrine of strict liability in the emerging field of product liability. ${ }^{45}$ An interpretation of Calabresi's historical role requires us to speculate on how his formal inquiry contrived to support his political agenda. Since Faustian imagery enters into his own book, let me suggest that Calabresi himself made a Faustian bargain with the new tools of welfare economics, which appeared magically on his doorstep as he began his academic career. Like many other social scientists of this decade, he explained his project as searching for theoretically secure microfoundations to ground his policy proposals. If his favoured policies could be deduced as theorems from the overarching logic of welfare economics, it follows, he could trump his political opponents with scientific, objective prescriptions. ${ }^{46}$

The movement to strict liability for manufacturers was already expanding through the decisions of State court judges, and it was strengthened in 1965 when the prestigious American Law Institute endorsed $\S 402 \mathrm{~A}$ of the Restatement (Second) of Torts. This trend was championed by socially progressive commentators of the $1950 \mathrm{~s}$ and $1960 \mathrm{~s}$, to whom its utilitarian benefits seemed too obvious to need much backing. In contrast to the distributively neutral problem of automobile injuries, this contest between consumers and producers recalled something of the older class conflict in workers' compensation. James's pioneering essays, among others, tried to supplement the trend toward strict liability with a set of economic arguments. When it came to designing safer products, ensuring quality control, and promoting consumer education, according to James, it was often most

45 For an excellent assessment of James' work, see Patrick S Atiyah "American Tort Law in Crisis" (1987) 7 J Legal Stud 279-301. The background to James is thoroughly explored in G Edward White Tort Law in America: An Intellectual History (Oxford University Press, New York, 1985).

46 Most notably he criticised Blum and Kalven's defence of the tort system for failing to show that tort achieves "optimal" results. Guido Calabresi "Fault, Accidents, and the Wonderful World of Blum and Kalven" (1965) 75 Yale L J 238. 
"efficient" for the manufacturer to take the initiative. In an age of private insurance, where the moral stigma of tort law had been attenuated, strict liability was a modern tool for imposing the initiative for safety where it most belonged-not for moral reasons, but for economic ones. To progressive liberals like James, who were skeptical of the caveat emptor ideology of free markets, ${ }^{47}$ it seemed obvious that manufacturers had excessive power to dictate terms to consumers. Consumers thus deserved the protection of strict liability rules.

Calabresi's work supplied the "microfoundations" for this Jamesian policy, supporting it with an elegant theoretical structure, and building his case on logic rather than empirical evidence. Calabresi made the case for strict liability rules (imposed by whom was not at all clear), but sidestepped the distributive arguments that were prominent in James's work. It all rested on the neutral values of cost efficiency: manufacturers were generally in a better position to reduce the costs of accidents (they were arguably the "cheapest cost-avoiders"). To be clear about it: the goal was not mere prevention. The sophisticated theorist called instead for "optimal prevention", which meant capping the investment in prevention at the level of compensation payments. For the sake of optimal prevention, the price of compensation must be brought home to the manufacturerdefendants who are in the best position to avoid future injuries. Similarly, before these manufacturer-defendants can impute correct prices for compensation costs, the legal system (or someone) must channel all worthy plaintiffs to precisely those defendants whose actions "caused" the underlying (and presumably on-going) damage. The policy recommendations turn out to be the same strict liability policies favoured by James and others, but the rationale is different. Instead of promoting fairness in distribution, the strict liability regime promotes efficient allocation of resources in pursuit of optimal prevention. Not too much prevention, but also not too little- just the right or "optimal" amount.

Calabresi's Faustian bargain comes down to this. For the sake of an earthly principle (strict liability to the manufacturer) he invested in the conceptual revolution that would ultimately undermine his "non-scientific" policy preferences. In order to make strict liability the recommendation of a neutral economic calculus, Calabresi had to embrace the broader principle that accident prevention costs should be capped at the limits of compensation. ${ }^{48}$ Reading between the lines, he was willing to accept this central premise, if it allowed him to deduce strict liability to manufacturers as a neutral corollary. All he really needed to make this deduction work was the

47 Compare James Buchanan "In Defense of Caveat Emptor" (1970) 38 U Chi L Rev 74. Buchanan supplements his economic arguments with a theory of justice derived from consent of sovereign individuals. His disciples try to resolve questions of legitimacy by reference to putative (or sometimes actual) contracts, constitutional pacts, and other artifices of consent. As philosophy Buchanan's approach satisfies many who share his libertarian values, including many in New Zealand.

48 Patrick Atiyah noted the "irony" that James's progeny would embrace market models, when the Jamesian approach was so clearly based on skepticism toward markets. Patrick S Atiyah "American Tort Law in Crisis" (1987) 7 J Legal Stud 301 sees this irony as "the source of the crisis of modern American tort law". 
concept of cost internalisation, borrowed from standard welfare-economic theory. The "decision for accidents" can go on automatic pilot, according to this notion, so long as the costs of compensation are imposed on those who typically control investments in prevention. The Calabresian theorist never leaves this abstract world of algebraic relations. Having set qualitative limits to prevention by restricting it to the sum of any and all compensation, Calabresi hurries past the vexing question of what should be the proper level of compensation. Calabresi does not locate this question within his formal scheme, although his Chicago School adversaries certainly would; and political opponents of strict liability were ready to propagate the new Chicago wisdom.

\section{F Theory Tilts to the Right}

Following the ingenious contributions of Richard Posner and Richard Epstein, ${ }^{49}$ high-level tort theory exploded in the academic literature. Posner's journals promoted extensive analytical studies for the remainder of the decade, and beyond. The parallel work of Ronald Coase and members of the Virginia School provided a fund of theorems rich enough to sustain a permanent, specialised literature. ${ }^{50}$ In addition, largely in response to the aggressive utilitarianism of welfare economics, other tort scholars sought equally radical foundations in neo-Kantian moral theory. ${ }^{51}$ By 1980 this new literature of "corrective justice" did far more than to "correct" the shadowy treatment of justice in the welfare economics literature: it built an entire normative defence of tort law around notions of individual desert and interpersonal reciprocity (not to say retribution). The earlier debate over "nofault" remained lost beyond all recognition in these scholastic battles. ${ }^{52}$ A few writers tried to recapture the comprehensive reform spirit of the Woodhouse era, but were politely ignored

49 The opening shots were fired in Richard Posner "A Theory of Negligence" (1972) 1 J Legal Stud 29 and Richard Epstein "A Theory of Strict Liability" (1973) 2 J Legal Stud 151. On the Posner phenomenon, see Cento G Veljanovski "Wealth Maximization, Law and Ethics-On the Limitations of Economic Efficiency" (1981) 1 Int'l Rev of Law and Economics 5.

50 The Coase article is one of the century's most frequently cited articles: Ronald Coase "The Problem of Social Cost" (1960) 3 J of Law and Economics 1. Members of the Virginia School include James M Buchanan. His 1965 book with Gordon Tullock, James M Buchanan and Gordon Tullock The Calculus of Consent (University of Michigan Press, Ann Arbor, 1965) was influential in transfering welfare-economic methods into political science and law. See also his volume edited with Robert D Tollison, James M Buchanan and Robert D Tollison Theory of Public Choice: Political Applications of Economics (University of Michigan Press, Ann Arbor, 1972).

51 Izhak Englard provides a critique of the first years of this movement: Izhak Englard The Philosophy of Tort Law (Aldershot, Dartmouth, 1992) chap 2. Equally insightful is his review of American tort theorists in the late 1970s: Izhak Englard "The System Builders: A Critical Appraisal of Modern American Tort Theory" (1980) 9 J Legal Stud 68.

52 By 1987 Patrick S Atiyah was ready to concede that "American tort law has become one big mess" (Patrick S Atiyah "American Tort Law in Crisis" (1987) 7 J Legal Stud 300). 
(including my own work on American policy in 1989). Others took on the Herculean task of applying empirical evidence to the abstractions of high theory, with mixed results..$^{53}$

Over time welfare economics drifted steadily rightwards-although it remains a matter of interpretation whether this was the cause or effect of the neo-liberal turn in American politics. Reformers with a progressive social agenda faced a dilemma. By the late 1970s, academic conventions had accepted welfare-economic theory (and its implied market norms) as a neutral method of inquiry - if not the only such method. To be sure, other schools soon emerged in competition, including some that attacked the entire discipline of neo-classical economics. ${ }^{54}$ Some new way forward needed to be found, but it proved difficult to escape the straitjacket of conceptual frameworks. The partisan struggles Calabresi wanted to avoid were reasserting themselves, exploiting tacit norms embedded in abstract theory.

In an age of eroding confidence in government, welfare economics naturally fills the normative vacuum vacated by politics. Calabresi's elegantly structured theory provides a roadmap for this rightward journey, tracing a route Calabresi himself strenuously resisted. His argument was spread across three separate planes, each of which carries a presumptive (but not conclusive) commitment to market solutions. On the first and most fundamental level, as explained above, Calabresi locates his master cost ratios of prevention and compensation. At this level, Calabresi wants the "decision for accidents" to emerge spontaneously from the market decisions of actors who stand ready to prevent only those accidents for which avoidance costs are cheaper than compensation. This theorem is revolutionary enough, compared to the no-fault arguments that preceded it, but Calabresi knows that it begs further questions.

In particular, it begs a second level of inquiry about the proper sum of compensation, on which economic actors base their individual decisions about accidents. Along with everybody else, Calabresi wants the costs of compensation to be "internalised"—or visited upon those actors who can prevent future accidents most cheaply. But he does not tell us exactly what these compensation benefits should be, whoever ends up paying the bill. In prior no-fault debates, some plans wanted benefits scaled to minimal levels of social security, while others wanted to replicate the categories of common law damages. But welfare economics prefers an answer generated by marketsassuming we can imagine a consumers' market where individuals bargain (in advance) for insurance against particular hazards and at particular levels of their own sovereign choice. Calabresi uses

53 See Stephen D Sugarman "Doing Away with Tort Law" (1985) 73 Cal L Rev 555; Richard Gaskins Environmental Accidents (Temple University Press, Philadelphia, 1989). Several empirical studies grew out of a massive, multi-year project sponsored by the American Law Institute and others. For summaries see Don Dewees Exploring the Domain of Accident Law: Taking the Facts Seriously (Oxford University Press, New York, 1996).

54 Among these schools was Critical Legal Studies. See Allan C Hutchinson "Beyond No-Fault" (1985) 73 Cal L Rev 755. 
sociological and psychological literature to raise doubts about entrusting this choice to market models. One wonders, though, why Calabresi trusts these hypothetical markets any less than that larger marketplace where rational calculators "choose" whether to cause or prevent future accidents. In partly removing the "choice for compensation" from markets, Calabresi may not have met the high burden of proof imposed by his own model — and so he was told by Posner and others. ${ }^{55}$ In classic Chicago style, Posner posited pure insurance markets dominated by consumer choice, and he concluded that Calabresi's approach would most likely overcompensate people. Overcompensation commits the sin of cost "externalisation" and would thus corrupt the higher-level calculus of optimal prevention. Critics like Posner did not have to prove that Calabresi was wrong - only that his nonmarket solutions failed to meet the burden of proof stacked against him by his own model. No empirical evidence can decide this question in concrete cases; it is rather a matter of each theorist's confidence in hypothetical market norms.

As formal economics advanced new theorems to suggest the impotence of government policy during the 1980s, Calabresi's burden grew even larger. Throughout his writings he argued consistently for at least some State interventions in market systems, as part of a third layer of analysis. Sometimes he based his argument on subjective notions of justice, but at other times he wanted to bolster the integrity of markets themselves. Whether he was right or wrong, Calabresi and his supporters had to make a case for some "optimal" level of market regulation. It is an argument that cannot be decided by empirical data, and all the presumptions of welfare economics and consumer sovereignty push against it.

\section{THE FUTURE OF NO-FAULT: LESSONS FROM THE PAST}

Every generation needs to find its own vision for accident compensation and prevention, based on its own definition of "accidents." In moving forward, it helps to look back at our inherited assumptions, which are still firmly embedded in current policies and debates. The fate of no-fault in America was sealed by 1980 - the moment when welfare-economics changed the whole tone and substance of prior debate, using an analytical framework that seemed innovative in the 1960s. The issue today is not whether we should use welfare-economic tools, which are obviously here to stay, but whether this framework can also provide the broader social principles for future policy. As we look ahead to the new century, it may be time for a different vision.

Much has changed in the world since the 1960s - in politics and the economy, as well as in society and technology. For all its success in creating new wealth and technology, the developed world remains a perilous place. Where once we measured that peril according to a table of maims, now the risk to personal well-being is much more diffuse. Such risk still includes disabling injuries,

55 As Morton J Horwitz wrote, liberals like Calabresi "were forced to treat tort law as a high transaction cost exception to a contract paradigm which claimed to best reflect the principle of consumer choice": "Law and Economics: Science or Politics?" (1980) 8 Hofstra L Rev 905, 908. 
but now it encompasses a wider, more complex range of causes and agents than was commonly imagined four decades ago. The difference goes beyond the chronic stresses and strains of the modern workplace, and includes the long-term health consequences of modern industrial systems, changing socio-economic structures, and our altered natural environment. Today the very notion of "risk" points beyond the injuries themselves to multiple, overlapping risk factors in the areas of health, environment, income, family structure, community strength. ${ }^{56}$ As we learn more about injuries in relation to these diverse factors, we also learn how much remains unknown. It seems to me we cannot rely on any policy framework that assumes we have already found (or could somehow engineer) a perfect balance between risk and response, agent and consequence, singular cause and containable effect.

In my view, the persistence of welfare-economic models over the past twenty years or more has postponed the discovery of new social responses to risk. That delay was not some evil conspiracy, but simply reflects the historic retreat of the state from its prior stewardship of social relations and social justice. In the field of accidents, political institutions were overmatched in addressing complex risk factors that were already evident by the 1950s, even as Americans were gearing up for our pedestrian debates about "no-fault". As the environmental movement surmised in the 1960s, continual advances in scientific knowledge have expanded the frontiers of uncertainty, presenting us with a host of ill-defined risk factors at the margins of progress. It may well turn out that modern inequality derives more from the distribution of risk than from the distribution of wealth or income. Of course the whole calculus of distribution vanished from the American political agenda back in the 1970s. Both then and now, our desire to respond to such challenges exceeds the capacities of our political and ethical systems. The retreat into welfare economics in the 1970s seems like a rearguard effort to avoid renegotiating social responsibilities. If that is indeed what happened, we need to look for some new framework.

Instead of the tunnel vision of welfare economics, we need to broaden our understanding of the accident problem, putting the victims' losses (and all the other social costs of accidents) back into the public equation. We also need to enlist all our social institutions in finding new solutionsstates as well as markets, principles of justice as well as principles of efficiency. A broader vision changes the emphasis from traditional categories of accidents that focus too narrowly on single causes - workplace accidents, automobile accidents, defective products, and all the rest. This shift is necessary not only for finding new approaches to compensation and financing, but also for accident prevention. Economics remains vital to any public response, but we need new models to meet the conditions of a dynamic world. We need economic models that leave behind the static analysis of the 1950s and embrace the more ragged capitalism of "creative destruction". Within

56 On these issues see Martin Carnoy Sustaining the New Economy: Work, Family, and Community in the Information Age (Harvard University Press, Cambridge, 2000); Niklas Luhmann Risk-A Sociological Theory (DeGruyter, New York, 1993). 
academic economics, some theorists are replacing the model of self-executing markets with the organic relations of network capitalism. ${ }^{57}$ Additional work includes reclaiming the concept of social cost from the dominant influence of Ronald Coase. In addition to measuring the empirical toll of personal injury on victims and society, we need better estimates of losses that fall outside the market calculus altogether. A suitable replacement for Coase has long been available in the model of social cost developed by economist K William Kapp. Influenced by European and American institutionalism, Kapp rejected the notion that social costs can be reduced to implied market choices, occasioned by Coase's postulated "transaction costs." According to Kapp, social costs must be defined by the same social authority that sets the legal framework for market exchange. Acknowledging Kapp in a 1961 article, Calabresi conceded that Kapp's treatment of social costs was correct "in theory". But he declined to follow it, based on the curious (and circular) argument that Kapp's social costs were too costly to calculate. ${ }^{58}$

For principles of equity, responsibility, and even efficiency, Americans should consider revisiting the Woodhouse Report as a fresh source of innovative thinking. In contrast to the contemporary American debate, the Woodhouse Commission was trying to find a new policy framework. It was comprehensive in several ways that American contributions never were. For example, it brought multiple social objectives into the mix-including the functions of social welfare. It obviously looked beyond traditional causal categories to define injury in a broader fashion, even though, in practice, ACC retained those categories for reasons of financing the scheme. Most important, it preserved for democratic governance the authority to provide definition and balance to the scheme. Whether democratic government in New Zealand, over time, was equal to that challenge needs to be more clearly understood. If not, we can hardly accuse New Zealand of political weakness greater than what was seen elsewhere in the world.

Even if we start fresh with the Woodhouse Report, the question remains where we go from there. Thirty-five years later, the search for a new vision is likely to move in different directions. Most important, in my opinion, is to find some broader social response to problems of prevention, including both health and safety. To be sure, the Woodhouse Commission listed prevention as its highest priority. But the Commission's views on complex causation must have made it difficult to imagine bold or comprehensive strategies for prevention, in contrast to the area of compensation.

57 See Dirk Messner The Network Society: Economic Development and International Competitiveness as Problems of Social Governance (Frank Cass, London, 1997); J Rogers Hollingsworth and Robert Boyer (eds) Contemporary Capitalism: The Embeddedness of Institutions (Cambridge University Press, Cambridge, 1997).

58 For an introduction to Kapp, see K William Kapp "On the Nature and Significance of Social Costs" (1969) 22 Kyklos 334. For a summary of Kapp's career, see Regine Heidenreich "Economics and Institutions: The Socioeconomic Approach of K William Kapp" (1998) 32 J of Economic Issues 965. For Calabresi on Kapp, see Guido Calabresi "Some Thoughts on Risk Distribution and the Law of Torts" (1961) 70 Yale L J 499, $532-33$. 
The definition of injury was still relatively simple back in 1967, even if the mechanisms for prevention were not. ${ }^{59}$ Today we know much more about prevention in complex fields of multiple causation, multiple agents and organisations, and multiple points of leverage for distributing risk. The welfare-economic reduction of prevention to economic incentives was a delusion-not because incentives are unimportant, but because they are never sufficient in a world outside of perfect markets. Starting also in the 1960s, epidemiologists and organisational theorists began developing a useful commentary on accident prevention, including both theory and empirical studies. ${ }^{60}$ Today there is a rich literature on these topics, best known within the Scandinavian countries, that could provide a new anchor for public policy in America.

The next great innovation for accident policies will be a vision for accident prevention that is as bold as Woodhouse's vision for compensation. It will deal comprehensively with issues of risk and responsibility in the complex environments of the twenty-first century. It will draw heavily on economics, but will not use economics reductively to finesse questions of politics and public values. There is no good reason why this search should not begin soon in the United States, where the problems of tort law, insurance coverage, administrative efficiency, and equity are no closer to solution than they were in 1965. But that search will more likely start elsewhere, and so why notonce again-New Zealand? The prerequisite is a fine understanding of ACC and its historical evolution. But the future will require important changes in ends and means, including closer alliance with other fields of public policy that are also coming to terms with problems of risk and responsibility.

59 William Vosburgh has suggested why it was easier to implement the compensation side of ACC than prevention, William Vosburgh "Primary Prevention, Priorities, and Implementation: The Case of the New Zealand Accident Compensation Act" in Felice D Perlmutter (ed) New Directions for Mental Health Services (Jossey-Bass, San Francisco, 1982).

60 For basic references see Richard J Bonnie Reducing the Burden of Injury (National Academy Press, Washington DC, 1999); Charles Perrow Normal Accidents (2 ed, Princeton University Press, Princeton, 1999). Earlier sources include J E Gordon "The Epidemiology of Accidents" (1949) 39 American J of Public Health 504; William Haddon Jr "Advances in the Epidemiology of Injuries as a Basis for Public Policy" (1980) 95 Public Health Reports 418. 
